\title{
STIMULASI MOTORIK DENGAN PERKEMBANGAN FISIK PADA ANAK USIA 3-5 TAHUN
}

\author{
Julio Ruauw \\ Sefti S.J Rompas \\ Lenny Gannika \\ Program Studi Ilmu Keperawatan Fakultas Kedokteran \\ Universitas Sam Ratulangi \\ Email : julioruauw0594@gmail.com
}

\begin{abstract}
Abstrack: Child development is all changes that occur in children that can be seen from various aspects, including physical aspects. Child development consists of motor development, cognitive development, and language development, where this development must be passed according to the period of development or according to the age of the child. Objective : To determine the relationship between motor stimulation and development in children aged 3-5 years in the Paslaten region. Method: This design uses quantitative descriptive research with cross sectional approach, using the chi-square test the number of population taken as many as 57 toddlers The sample used with the total sampling method. Conclusion: Relationship of Motor Stimulation with Physical Development of Toddlers Aged 3-5 Years in Paslaten Work Area of Remboken Health Center, Year 2019, and with this research it is expected that the results of this study can be readings of local Puskesmas in providing socialization to mothers who have children under five in the knowledge and development of children in the lives of children under five. Need to socialize for good nutrition so children can grow well according to the age of children under five.
\end{abstract}

Keywords: Motor Stimulation, Physical Development of Toddlers

\begin{abstract}
Abstrak : Perkembangan anak merupakan segala perubahan yang terjadi pada anak yang dapat dilihat dari berbagai aspek, antara lain aspek fisik. Perkembangan anak terdiri dari perkembangan motorik, perkembangan kognitif, dan perkembangan bahasa, dimana perkembangan ini harus dilalui sesuai periode perkembangan atau sesuai umur anak. Tujuan Penelitian : Untuk mengetahui hubungan stimulasi motorik dengan perkembangan pada balita usia 3-5 tahun didesa Paslaten wilayah. Metode : Desain ini menggunakan penelitian deskriptif kuantitatif dengan pendekatan cross sectional, dengan menggunakan uji chi-square jumlah populasi yang di ambil sebanyak 57 balita Sampel yang digunakan dengan metode total sampling. Penelitian ini dilaksanakan dengan mengikuti prinsip etik penelitian berdasarkan Komite Nasional Etik Penelitian Kesehatan dalam merupakan sebagai berikut:

Kesimpulan : Hubungan Stimulasi Motorik dengan Perkembangan Fisik Balita Usia 3-5 Tahun Didesa Paslaten Wilayah Kerja Puskesmas Remboken, Tahun 2019, dan dengan adanya penelitian ini diharapkan hasil penelitian ini dapat menjadi bahan bacaan Puskesmas setempat dalam memberikan sosialisasi kepada ibu - ibu yang memilki anak balita dalam pengetahuan dan perkembangan anak dalam kehidupan anak balita. Diketahui bahwa sebagian besar responden mempunyai kategori yang memiliki perkembangan normal.
\end{abstract}

Kata Kunci : Stimulasi Motorik, Perkembangan Fisik Balita. 


\section{PENDAHULUAN}

Masa balita merupakan waktu yang sangat penting dan sangat berpengaruh terhadap perkembangannya. Pada saat inilah penting untuk merencanakan terkait dengan perkembangan seorang anak. Perkembangan anak merupakan segala perubahan yang terjadi pada anak yang dapat dilihat dari berbagai aspek, antara lain aspek fisik. Perkembangan anak terdiri dari perkembangan motorik, perkembangan kognitif, dan perkembangan bahasa, dimana perkembangan ini harus dilalui sesuai periode perkembangan atau sesuai umur anak (Soejatingsih, 2010).

Permasalahan gangguan perkembangan di tengah masyarakat dari tahun ke tahun khususnya di Indonesia masih belum teratasi. Kejadian ini dibuktikan oleh angka kejadian masalah perkembangan anak di dunia sekitar 12-16 $\%$, sedangkan prevalensi masalah perkembangan anak di Indonesia pada tahun 2013 sebesar 11-16\%. Pada tahun 2014 sebesar 10-14\% anak mengalami gangguan perkembangan sedangkan tahun 2015 sejumlah 13-18\% (Novianti, 2015). Data dari Dinkes Provinsi Jawa Timur terdapat $3-5 \%$ anak mengalami keterlambatan motorik. Data jumlah balita kabupaten Madiun pada Tahun 2015 berjumlah 2.449 balita yang mengalami keterlambatan perkembangan motorik sebanyak 906 atau 36,9\% balita (Depkes RI,2015).

Ikatan Dokter Anak Indonnesia
(IDAI) Jawa Timur melakukan pemeriksaan terhadap 2.634 anak dari usia 0-72 bulan. Hasil pemeriksaan tersebut menunjukkan hasil perkembangan normal sesuai usia 53\%, meragukan (Membutuhkan pemeriksaan lebih dalam) sebanyak $13 \%$ dan penyimpangan perkembangan sebanyak 34\%. $10 \%$ dari penyimpangan perkembangan tersebut terdapat pada aspek motorik kasar (seperti berjalan, duduk), $30 \%$ motorik halus (seperti Menulis, memegang), 44\% bicara bahasa dan $16 \%$ sosialisasi kemandirian (Cempaka, 2016).

Masalah yang di timbulkan oleh keterlambatan perkembangan salah satunya balita akan bermasalah dalam hubungan sosial awal dengan teman sebayanya, yang menyebabkan balita merasa kesepian dan tidak mempunyai kesempatan untuk berperilaku sesuai dengan teman sebayanya. Perkembangan selanjutnya setelah bertambah usia akan mempengaruhi kecerdasan emosi, kecerdasan mental anak dan kemungkinan jangka panjang anak secara kecerdasan IQ bagus namun kecerdasan EQ terlambat (Suhartini, 2011).

Stimulasi perkembangan motorik yang lambat dapat disebabkan oleh hal-hal tertentu seperti faktor keturunan dan faktor lingkungan. Faktor keturunan dimana pada keluarganya rata-rata perkembangan motorik lambat dan faktor lingkungan pula seperti anak tidak ada kesempatan untuk belajar karena terlalu dimanjakan, selalu digendong atau diletakkan di babywalker terlalu lama dan juga anak yang mengalami deprivasi meternal. Disamping itu, faktor kepribadian anak misalnya anak sangat penakut, gangguan retadasi mental juga adalah penyebab perkembangan motorik yang lambat. Selain itu, kelainan tonus otot, obesitas, penyakit neuromuscular seperti penyakit duchenne muscular dystrophy dan buta juga merupakan gangguan perkembangan motorik. (Soejatiningsih, 2012)

Sutrisno (2014), pada umumnya anak memiliki pertumbuhan dan perkembangan yang normal dan ini merupakan hasil interaksi banyak faktor yang mempengaruhi pertumbuhan dan perkembangan anak. Faktor-faktor tersebut meliputi genetic, lingkungan, mekanisme, 
toksin/zat kimia, gizi, hubungan anak dengan keluarga, stimulasi, dan APE (Alat Permainan Edukatif).

Sutrisno (2014), pada umumnya anak memiliki pertumbuhan dan perkembangan yang normal dan ini merupakan hasil interaksi banyak faktor yang mempengaruhi pertumbuhan dan perkembangan anak. Faktor-faktor tersebut meliputi genetic, lingkungan, mekanisme, toksin/zat kimia, gizi, hubungan anak dengan keluarga, stimulasi, dan APE (Alat Permainan Edukatif)..

Kenyataan yang ada di masyarakat tidak semua anak balita dapat berkembang secara normal. Seperti ketika anak sudah berumur satu tahun, anak sudah bisa berjalan. Namun terdapat anak yang mengalami terlambat berjalan, meski usia sudah lebih dari setahun. Salah satu penyebabnya merupakan kurangnya orang tua dalam merangsang motorik kasar pada anak. Orang tua selalu khawatir anak jatuh sehingga sering mengendongnya, hal ini juga akan membuat anak terlambat berjalan. Sebab otot-otot kaki anak tidak pernah mendapat stimulus untuk bergerak (Supratiknya.A. 1995).

Penilaian pertumbuhan dan perkembangan dapat dilakukan sedini mungkin sejak anak dilahirkan. Deteksi dini merupakan upaya penjaringan yang dilaksanakan secara komprehensif untuk menemukan penyimpangan pada tumbuh kembang anak. Upaya-upaya yang dapat dilakukan untuk perkembangan motorik anak secara optimal dapat dilakukan dengan memberikan stimulus, meningkatkan status gizi, APE (alat permainan edukatif) serta pola pengasuhan orang tua (Lindawati, 2014). Penilaian pertumbuhan dan perkembangan dapat dilakukan sedini mungkin sejak anak dilahirkan. Deteksi dini merupakan upaya penjaringan yang dilaksanakan secara komprehensif untuk menemukan penyimpangan pada tumbuh kembang anak. Upaya-upaya yang dapat dilakukan untuk perkembangan motorik anak secara optimal dapat dilakukan dengan memberikan stimulus, meningkatkan status gizi, APE (alat permainan edukatif) serta pola pengasuhan orang tua (Lindawati, 2014).

Hasil study pendahuluan yang dilakukan di desa Paslaten wilayah kerja Puskesmas Remboken Kecamatan Minahasa terdapat 57 balita usia 3-5 tahun. Berdasarkan hasil wawancara dan observasi langsung yang dilakukan pada salah satu perawat didapatkan di puskesmas dan Ibu anak ada 4 anak balita yang mengalami keterlambatan perkembangan fisik, dari 10 balita usia 3-5 tahun. Hal ini menunjukan bahwa masih ada anak yang memiliki keterlambatan Stimulasi motorik di tempat tersebut. Hasil tersebut didapatkan dari penilaian Puskesmas Remboken karena data yang diperlukan yaitu keterlambatan motorik terdapat pada lokasi tersebut.

\section{METODE PENELITIAN}

Desain ini menggunakan penelitian deskriptif kuantitatif dengan pendekatan cross sectional. Dimana pengambilan variabel dependent (terikat) dan independent (bebas) dilakukan secara bersamaan (Notoatmodjo, 2012). Lokasi Penelitian telah dilakukan di Desa Paslaten Wilayah Kerja Puskemas Remboken, Waktu Penelitian ini, Penelitian telah dilaksanakan pada bulan Juni 2019.

Populasi merupakan keseluruhan subjek penelitian (Nursalam, 2008). Populasi pada penelitian ini adalah orang tua yang mempunyai anak usia 3-5 tahun di Desa Paslaten sebanyak 57 orang.

Sampel pada penelitian ini diambil total sampling.

Kuesioner untuk memperoleh
informasi dari responden, peneliti menggunakan alat pengumpulan data berupa kuesioner untuk perkembangan motorik anak yang berjumlah 10 pertanyaan dengan pilihan jawaban SM: Sangat Mampu, M: Mampu, KM: Kurang Mampu, SKM Sangat Kurang Mampu Untuk skor nilai median, yaitu: Skor terendah x jumlah pertanyaan: 1 x $10=10$,Skor tertinggi $\mathrm{x}$ 
jumlah pertanyaan: $4 \times 10=40$, Nilai median yang diperoleh adalah: $(10+40)=$ $50: 2+1=26$, Nilai median " 26 " selanjutnya sebagai cut off point (Sunyoto dan Setiawan, 2013) Normal > 26 dan Abnormal $\leq 26$ dengan pilihan jawaban SL (Selalu), SR (Sering), R (Jarang) dan TM (Tidak)Melakukan Untuk skor nilai median, yaitu:

Skor terendah x jumlah pertanyaan: 1 x 10 $=10$, Skor tertinggi $\mathrm{x}$ jumlah pertanyaan: 4 $\mathrm{x} 10=40$, Nilai median yang diperoleh adalah: $(10+40)=50: 2+1=26$ Nilai median "26" selanjutnya sebagai cut off point (Sunyoto dan Setiawan, 2013) baik jika > 26 dan buruk jika $\leq 26$.Analis yang menggunakan analisis Univariat terhadap variabel penelitian untuk melihat tampilan distribusi frekuensi dan persentase dari tiaptiap variabel.

\section{Analisa Bivariat}

Analisa bivariat merupakan analisa yang digunakan untuk melihat hubungan antara variabel bebas dengan variabel terikat yang di duga berhubungan atau berkorelasi (Notoatmodjo, 2012). Uji statistik yang digunakan adalah Chi-Square dengan derajat kepercayaan 95\%. Jika angka signifikansi hasil $<0.05$, maka terdapat adanya hubungan antara variabel signifikan atau menunjukkan hubungan bermakna. Jika angka signifikansi hasil riset $>0.05$, maka tidak terdapat adanya hubungan antara variabel tidak signifikan atau menunjukkan hubungan tidak bermakna.

Prosedur pengolahan data yang dilakukan yaitu:

\section{a. Editing}

Proses editing dilakukan setelah data terkumpul dan dilakukan dengan memeriksa kelengkapan data, memeriksa kesinambungan data, dan memeriksa keseragaman data.

\section{b. Coding}

Untuk memudahkan pengolahan data, semua jawaban atau data disederhanakan yaitu dengan memberikan simbol-simbol tertentu untuk setiap jawaban. Tabulasi dilakukan setelah seluruh variabel dikoding. Data yang telah dikoding kemudian dimasukkan terlebih dahulu kedalam master tabel. Entri data dapat dilakukan dengan cara manual atau dengan paket program komputer.

c. Cleaning

Untuk meyakinkan bahwa data yang telah dientri/dimasukkan betul-betul bersih dari kesalahan. Penelitian ini dilaksanakan dengan mengikuti prinsip etik penelitian berdasarkan Komite Nasional Etik Penelitian Kesehatan dalam (Nursalam, 2009) adalah sebagai berikut:

\section{d.Informed consent}

Lembar persetujuan ini akan diberikan kepada responden (Ibu) yang memenuhi kriteria inklusi. Jika subjek menolak, peneliti tidak memaksa dan menghormati hak-hak mereka.

e. Anonomity (tanpa nama)

Untuk menjaga kerahasiaan, peneliti tidak akan mencantumkan nama responden, tapi lembar tersebut deberikan kode atau inisial. f. Confidentially

Kerahasiaan informal responden dijamin oleh peneliti dan hanya data-data tertentu yang akan dilaporkan sebagai hasil peneitian. Penelitian ini dilaksanakan dengan mengikuti prinsip etik penelitian berdasarkan Komite Nasional Etik Penelitian Kesehatan.

\section{HASIL dan PEMBAHASAN}

Tabel 1. Distribusi berdasarkan Umur Ibu yang memiliki balita di Desa Paslaten wilayah kerja Puskesmas Remboken, Tahun 2019

\begin{tabular}{|c|c|c|}
\hline $\begin{array}{l}\text { Umur } \\
\text { Responden }\end{array}$ & $\mathrm{n}$ & $\%$ \\
\hline$>25$ Tahun & 33 & 57.9 \\
\hline$<25$ Tahun & 24 & 42.1 \\
\hline Total & 57 & 100.0 \\
\hline
\end{tabular}

Berdasarkan tabel 1 diketahui bahwa sebagian besar umur responden ibu yang memiliki anak balita berada pada umur $>25$ tahun yakni sebanyak 33 responden $(57.9 \%)$, dan pada kelompok umur $<25$ tahun sebanyak 24 responden $(42.1 \%)$. 


\section{Analisa Univariat}

Tabel 2. Distribusi berdasarkan stimulasi motorik anak di Desa Paslaten wilayah kerja Puskesmas Remboken, Tahun 2019

\begin{tabular}{lcc}
\hline $\begin{array}{l}\text { Stimulasi } \\
\text { Motorik }\end{array}$ & $\mathrm{n}$ & $\%$ \\
\hline Baik & 37 & 64.9 \\
Buruk & 20 & 35.1 \\
\hline Total & 57 & 100.0 \\
\hline
\end{tabular}

Sumber data: Data Primer 2019

Berdasarkan tabel 2 diketahui bahwa sebagian besar responden mempunyai kategori stimulasi baik yaitu sebanyak 37 anak balita (64.9\%), dan balita yang memiliki stimulasi motorik buruk sebanyak 20 balita $(35.1 \%)$. Perkembangan Fisik Balita.

Tabel 3. Distribusi berdasarkan perkembangan fisik balita di Desa Paslaten wilayah kerja Puskesmas Remboken,

Tahun 2019

\begin{tabular}{lcc}
\hline Perkembangan Fisik & $\mathrm{n}$ & $\%$ \\
\hline Abnormal & 19 & 33.3 \\
Normal & 38 & 66.7 \\
\hline Total & 57 & 100.0 \\
\hline
\end{tabular}

Sumber data: Data Primer 2019

Berdasarkan tabel 3 diketahui bahwa sebagian besar balita mempunyai kategori perkembangan fisik normal yaitu sebanyak 38 balita (66.7\%) dan balita yang memiliki perkembangan fisik yang Abnormal sebanyak 19 balita (33.33\%). Perkembangan Stimulasi motorik yang baik pada anak yaitu anak bisa melakukan pergerakan tubuh sambil mengikuti ibu yang mengajarkan, anak juga sudah bisa menggambar, memegang suatu benda, balita juga bisa merespon suara saat dipanggil namanya, mengikuti perintah dan bisa berbicara spontan. Anak dengan perkembangan stimulasi yang buruk adalah anak yang tidak bisa besosialisasi dengn lingkungan, anak juga tidak bisa tidak bisa berkomunikasi dengan baik pada umur 3 sampai 5 tahun. Suhartini (2011).
Tabel 4. Hubungan Stimulasi Motorik dengan Perkembangan Fisik Anak Usia 3-5 Tahun Didesa Paslaten Wilayah Kerja Puskesmas Remboken, Tahun 2019

\begin{tabular}{|c|c|c|c|c|c|c|c|}
\hline \multirow{3}{*}{$\begin{array}{l}\text { Stimulasi } \\
\text { Motorik }\end{array}$} & \multicolumn{4}{|c|}{ Perkembangan Fisik } & \multirow{2}{*}{\multicolumn{2}{|c|}{ Total }} & \multirow{3}{*}{$\begin{array}{c}\rho \\
\text { Value }\end{array}$} \\
\hline & \multicolumn{2}{|c|}{ Abnormal } & \multicolumn{2}{|c|}{ Normal } & & & \\
\hline & $\mathrm{n}$ & $\%$ & $\mathrm{n}$ & $\%$ & $\mathrm{n}$ & $\%$ & \\
\hline Baik & 8 & 14,0 & 29 & 50,9 & 37 & 64,9 & \\
\hline Buruk & 11 & 19,3 & 9 & 15,8 & 20 & 35,1 & 0,024 \\
\hline Total & 19 & 33,3 & 38 & 66,7 & 57 & 100 & \\
\hline
\end{tabular}

Berdasarkan hasil tabulasi silang menunjukan bahwa sebanyak 20 anak balita $(35.1 \%)$ yang mempunyai stimulasi motorik buruk, terdapat 11 responden $(19.3 \%)$ yang memiliki perkembangan fisik abnormal, dan terdapat 9 responden $(15.8 \%)$ yang memiliki perkembangan fisik normal. Terdapat sebanyak 37 anak balita (64.9\%) yang memiliki stimulasi motorik baik, terdapat 8 anak balita (14.0\%) yang memiliki perkembangan fisik yang abnormal dan sebanyak 29 anak balita (50.9\%) yang memiliki perkembangan fisik normal. Hasil analisis dengan menggunakan uji Chi-Square memperoleh nilai signifikan $=0.001$ atau lebih kecil dari nilai $\alpha 0.05$ maka dengan demikian dapat disimpulkan bahwa terdapat hubungan stimulasi motorik dengan perkembangan fisik anak usia 3-5 Tahun diDesa Paslaten Wilayah Kerja Puskesmas Remboken.

\section{Pembahasan \\ Karakteristik Responden Umur}

Berdasarkan hasil Penelitian menunjukan bahwa sebagian besar umur ibu yang memiliki anak balita berada pada umur $<35$ tahun yakni sebanyak 33 responden (57.9\%), dan pada kelompok umur > 35 tahun sebanyak 24 responden (42.1\%). Hasil penelitian ini juga sejalan dengan penelitian yanga dilakukan oleh Yufi, 2016 dengan judul hubungan pemberian stimulasi dengan perkembangan motorik kasar pada bayi usia $12-24$ bulan, diketahui bahwa bahwa sebagian besar responden berusia 20-35 tahun yaitu 
sebanyak 36 responden (67\%) sedangkan sebagian kecil yaitu sebanyak 6 responden (11\%) berumur > 35 tahun. Menurut Imelda, 2017, menjelaskan bahwa semakin dewasa usia orang tua akan lebih memahami dalam mengasuh, mendidik dan mencukupi kebutuhan gizi anak sehingga mampu meningkatkan perkembangan anak dibandingkan usia orang tua yang lebih muda

\section{Hasil Univariat}

\section{Stimulasi Motorik}

Berdasarkan hasil menunjukan bahwa sebagian besar responden mempunyai kategori stimulasi baik yaitu sebanyak 37 anak balita (64.9\%), dan balita yang memiliki stimulasi motorik buruk sebanyak 20 balita (35.1\%). Hasil penelitian ini juga sejalan dengan penelitian yanga dilakukan oleh Sutrisno MY. (2014). dengan judul hubungan pemberian stimulasi dengan perkembangan motorik kasar pada bayi usia 12 - 24 bulan, ketahui bahwa yang memberikan stimulasi baik yaitu 38 responden $(70 \%)$ dan yang memberikan stimulasi cukup 5 responden (9\%).

Perkembangan Stimulasi motorik yang baik pada anak yaitu anak bisa melakukan pergerakan tubuh sambil mengikuti ibu yang mengajarkan, anak juga sudah bisa menggambar, memegang suatu benda, balita juga bisa merespon suara saat dipanggil namanya, mengikuti perintah dan bisa berbicara spontan. Anak dengan perkembangan stimulasi yang buruk adalah anak yang tidak bisa besosialisasi dengn lingkungan, anak juga tidak bisa tidak bisa berkomunikasi dengan baik pada umur 3 sampai 5 tahun. Suhartini (2011). Hasil penelitian ini sesuai teori yang dikemukakan Soetjiningsih (2010) Oki, 2016, bahwa kebutuhan dasar perkembangan anakpada faktor lingkungan memberikan pengaruh yang positif bagi tumbuh kembang anak dan dapat dikelompokkan menjadi: Asuh (Kebutuhan fisik - biomedis), Asih (Kebutuhan emosi dan kasih sayang), dan Asah (stimulasi) yaitu adanya rangsangan dari lingkungan luar anak, dapat berupa latihan atau bermain. Menurut Nursalam yang dikutip Rizki, 2016 bahwa pemberian stimulasi adalah perangsangan dan latihan-latihan terhadap kepandaian anak yang datangnya dari lingkungan di luar anak.

\section{Perkembangan Fisik}

Berdasarkan hasil menunjukan bahwa sebagian besar balita mempunyai kategori perkembangan fisik normal yaitu sebanyak 38 balita $(66.7 \%)$ dan balita yang memiliki perkembangan fisik yang Abnormal sebanyak 19 balita (33.33\%). Kurnia 2016 mengatakan bahwa perkembangan motorik anak sangat tergantung pada seberapa banyak stimulasi dan dorongan yang diberikan. Hal ini disebabkan karena otot-otot anak baik halus ataupun kasar belum mencapai kematangan. Dengan latihan-latihan yang cukup akan membantu anak untuk mengendalikan gerak ototnya sehingga mencapai kondisi perkembangan yang optimal yang ditandai dengan mampunya anak menyelesaikan tugas perkembangan sesuai usianya. Rizky, 2015 mengatakan bahwa semakin dini stimulasi yang diberikan, maka perkembangan anak akan semakin baik. Semakin banyak stimulasi yang diberikan maka pengetahuan anak menjadi luas sehingga perkembangan anak semakin optimal.

\section{Hasil Bivariat}

Berdasarkan hasil tabulasi silang menunjukan bahwa sebanyak 20 anak balita (35.1\%) yang mempunyai stimulasi motorik buruk, terdapat 11 responden $(19.3 \%)$ yang memiliki perkembangan fisik abnormal, dan terdapat 9 responden $(15.8 \%)$ yang memiliki perkembangan fisik normal. Terdapat sebanyak 37 anak balita $(64.9 \%)$ yang memiliki stimulasi motorik baik, terdapat 8 anak balita $(14.0 \%)$ yang memiliki perkembangan fisik yang abnormal dan sebanyak 29 anak balita (50.9\%) yang memiliki perkembangan fisik normal. Hasil analisis dengan menggunakan uji Chi-Square memperoleh 
nilai signifikan $=0.01$ atau lebih kecil dari nilai $\alpha 0.05$ maka dengan demikian dapat disimpulkan bahwa terdapat Hubungan Stimulasi Motorik dengan Perkembangan Fisik Balita Usia 3-5 Tahun Didesa Paslaten Wilayah Kerja Puskesmas Remboken, Tahun 2019.

Hasil penelitian ini sejalan dengan penelitian yanga dilakukan oleh Imelda, 2017. dengan judull hubungan stimulasi dengan perkembangan motorik halus pada anak usia 48-60 bulan di smart school anduonohu kota kendari tahun 2018 dengan hasil uji statistik chi-square dengan tingkat kemaknaan $\alpha=0,05$ di peroleh nilai $p=0,021$ yang berarti bahwa ada hubungan stimulasi dengan perkembangan motorik halus. stimulasi di tahap ini masih terdapat stimulasi buruk dan perkembangan anak yang abnormal di desa Paslaten di wilayah kerja Puskesmas karena masih banyak orang tua yang kurang memberikan waktu anak untuk mandiri dalam melakukan aktiftas bermain, ibu juga kurang mengajarkan bersosialisasi dengan lingkungan, dan kurangnya pemberian nutrisi sehingga anak balita pertumbuhannya abnormal. Ada juga anak yang stimulasinya baik tapi perkembangannya abnormal karena sesuai dengan fisik dan kondisi anak tersebut. Selain gangguan fungsi fisik dan psikomotor, perkembangan abnormal juga terdapat gangguan perkembangan berupa cacat mental. Terjadinya cacat mental disebabkan oleh dua factor, yaitu factor organik dan faktor non organik. Faktor organik berupa faktor prakonsepsi, faktor prenatal, faktor prenatal premature asfiksi, dan faktor post natal. Sedangkan faktor non organik berupa kemiskinan dan keluarga yang tidak harmonis, faktor sosiokultural, interaksi anak dengan pengasuh kurang baik, dan lain sebagainya.gangguan fungsi fisik dan psikomotor serta cacat mental, gangguan yang lain yang ditimbulkan akibat perkembangan abnormal, yaitu gangguan psiko sosial dan perilaku. Dalam gangguan ini dapat menimbulkan Autistik, anak sukar didik, anak dengan gangguan belajar, anak nakal/delinkuensi, alienasi atau pecandu, dan rehabilitasi cacat. Supratiknya.A. (1995)

\section{SIMPULAN}

Diketahui bahwa sebagian besar responden mempunyai kategori stimulasi motorik baik dan perkembangan fisik yang baik. diketahui bahwa sebagian besar responden mempunyai kategori yang memiliki perkembangan normal. ada hubungan stimulasi motorik dengan perkembangan fisik balita usia 3-5 tahun didesa Paslaten wilayah kerja Puskesmas Remboken, Tahun 2019.

\section{DAFTAR PUSTAKA}

Cempaka. (2016). Hubungan Stimulasi perkembangan Terhadap Perkembangan Anak Usia 0-5 tahun di RW Kelurahan Kalicari Kota Semarang.

eprints.undip.ac.id/49601/1/PROPO SAL_BUNEG.pdf. didownload pada tanggal 04 Februari 2019 pukul 20.00 WIB

Cintya dkk. (2015). Teori dan Konsep Tumbuh Kembang. Jogjakarta: Nuhamedika.

Departemen Kesehatan RI.2015.

\section{DeteksiDini Tumbuh \\ Kembang Balita.}

http://www.indonesian-

publichealth.com/deteksi-dini-

tumbuh-kembang- balita/. Di download pada tanggal 04 Februari 2019 pukul 22.10 WIB

Imelda, 2017. Pengetahuan Ibu Tentang Pemberian Stimulasi Dan Perkembangan Anak Pra Sekolah (35 Tahun) Di Banda Aceh, Jurnal

Kurnia, 2016. Perkembangan Motorik Kasar Anak Usia Pra Sekolah Gross Motor Development Of Preschools Children, Jurnal 
Lindawati. (2014). Faktor-faktor yang Berhubungan dengan Perkembangan MotorikAnak Usia Pra

Sekolah.eprints.ums.ac.id/46410/8/

DAFTAR\%2OPUSTAK.pdf. Di download pada tanggal 02 Februari 2019 pukul 20.00 WIB.

Novianti, (2015). Meningkatkan Perkembangan Motorik Kasar Anak Kelompok B2 Semester II Tk Widya Santhi. e-journal PG-PAUD : Universitas Pendidikan Ganesha, Vol 3 (1). Diunduh pada tanggal 1 Oktober 2015.

Notoatmodjo, S. (2012). Metodologi Penelitian Kesehatan. Jakarta: Rineka Cipta.

Nursalam, (2008). Konsep dan Penerapan Metodologi Penelitian Ilmu Keperawatan Jakarta: Salemba Medika

Oki, 2016 Perbedaan Pertumbuhan Fisik Dan Perkembangan Motorik Kasar Siswa Laki-Laki Dan Perempuan Kelas Atas Sdn Kalongan 4 Ungaran Timur, Jurnal.

Rizki. P, 2016 tingkat perkembangan anak pra sekolah usia 3-5 tahun yang mengikuti dan tidak mengikuti pendidikan anak usia dini (PAUD, Jurnal

Soetjiningsih. (2010). Buku Ajar Tumbuh Kembang Anak dan Permasalahanya. Jakarta: Sagung Seto.

Soetjiningsih. (2012). Tumbuh Kembang Anak. Jakarta: Kedokteran EGC.

Suhartini. (2011). Perkembangan Motorik Anak Toddler pada Ibu Bekerja dan Ibu Tidak Bekerja. http://journal.unair.ac.id/downloadfullpapers-pmnj26e02e4 f68full.docx .Didownload pada tanggal 02 Februari 2019 pukul 21.05 WIB.

Sunyoto \& Setiawan. (2013). Statistika Sebagai Pengertian Ilmu
Sutrisno MY. (2014). Hubungan Status gizi dengan perkembangan Motorik Kasar Anak usia 6-24 bulan di Posyandu Mandalawangi pandeglang Banten. repository.uinjkt.ac.id/dspace/.../MO HAMMAD\%20YOGI\%20SUTRISN O-FKIK.pdf diakses pada tanggal 19 Maret 2019 pukul 21.40

Supratiknya.A. 1995. Mengenal Perilaku Abnormal. Yogyakarta: Kanisius Mine coins - make money: http://bit.ly/money_crypto

Yufi, 2016. Hubungan pemberian stimulasi dengan perkembangan motoric kasar pada bayi usia 6-12 bulan di Desa Banjaragung Kecamatan Puri Kabupaten Mojokerto, Jurnal. 